\title{
MANAJEMEN STRATEGIK SEBAGAI PENDEKATAN DALAM MENGEMBANGKAN E-GOVERNMENT DI INDONESIA
}

\author{
S l a m e t \\ Fakultas Ekonomi Universitas Islam Negeri Maulana Malik Ibrahim Malang \\ Jalan Gajayana 50 Malang \\ slamet_uinmlg@yahoo.co.id
}

\begin{abstract}
ABSTRAK
In this information age, quick, precise and accurate dissemination and access information is absolutely necessary. Similarly, information is one of the organization's resources that have to be managed as well as other organizational resources. To facilitate the dissemination and access of expected information, information and communication technology (ICT) or commonly known as ICT (Information Communication \& Technology) has a dominant role in terms of process, storage, retrieval, and dissemination of information. The involvement of integrated ICT in government agencies with the goal of providing ease process of service to citizens is called e-government. E-government has advantages and enormous significance for all citizens. However, to realize the target of e-government requires a substantial investment, on the other hand, the implementation of ICT is often facing a failure or lack of a strategic benefit. Therefore, to avoid the failure of ICT implementation to realize the target of egovernment and pay attention to the amount of investment or budget, it is essential to manage the ICT department as the manager of e-government using strategic management as an approach. In here KPDE has a role as Chief Information Officer (CIO), which has the task of planning, implementer, coordinator, control and oversight of e-government implementation.
\end{abstract}

Keyword: manajemen, strategik, ICT, dan e-government .

Pada era informasi ini, penyebaran dan akses informasi secara cepat, tepat dan akurat merupakan hal yang mutlak diperlukan. Pada era ini pula, informasi merupakan salah satu sumber daya organisasi yang harus dimanaj secara baik, sebagaimana sumber daya organisasi yang lain. Untuk menjembatani penyebaran dan akses informasi yang diharapkan, teknologi informasi (TI) yang didukung oleh sarana komunikasi termasuklah internet, kini dikenali dengan istilah Information Technology and Communication (ICT) telah memainkan peran penting dalam kehidupan manusia sehari-hari. Seperti cara menjalankan pekerjaan, me-manaj organisasi, kebebasan berkomunikasi, akses informasi, kemudahan dan kecepatan dalam pertukaran informasi dan ketersebaran informasi yang selalu riel-time (up-to-date).

Dilihat dari sudut pandang organisasi, ICT memberikan sumbangan penting dalam membantu pihak manajemen dalam membuat perencanaan, pengawasan dan membuat keputusan secara efektif. Lebih penting lagi adalah merupakan enabler dalam sebuah organisasi, yaitu mampu menjadi model pelayanan yang berbasiskan ICT sehingga dapat menciptakan budaya kerja yang berpengetahuan. Kini, ICT tidak dapat dipisahkan lagi dari sebuah organisasi, baik organisasi yang bergerak di bidang bisnis (profit-oriented) maupun yang bergerak di bidang sosial (non-profit-oriented), tanpa berfikir berapa nilai investasi yang harus ditanamkan. Investasi di bidang ICT merupakan masalah yang sulit bagi pimpinan organisasi. Di satu pihak mereka sadar dan berfikir bahwa sudah saatnya organisasinya memiliki sistem informasi yang lebih baik - dan tentunya didukung oleh alat yaitu ICT untuk menunjang sistem kerja bagi organisasi mereka. Tanpa memiliki ICT yang cukup 
canggih, sulit pada lingkungan global ini untuk mampu bersaing atau memberikan pelayanan yang lebih baik kepada customer (Indrajit 2004). Di lain pihak, mereka juga berfikir harus mengeluarkan anggaran (budget) yang cukup besar (Kumorotomo \& Margono 1996).

Ditinjau dari segi perkembangannya, ICT memainkan peran penting, mulai peran efisiensi, efektivitas hingga kepada peran yang lebih strategik dan sebagai salah satu instrumen perubahan dalam organisasi. Untuk itu, ICT harus dipandang sebagai aset suatu organisasi yang bernilai ekonomis. Pemenuhan aset teknologi ini, diperlukan anggaran (budget) yang tidak sedikit, dalam organisasi bisnis merupakan investasi yang harus mendapatkan tingkat return tertentu. Selain itu, bagi organisasi bisnis (profit oriented), ICT dapat digunakan untuk menciptakan keunggulan dan memenangkan persaingan. Namun tidaklah demikian pada sektor pemerintahan atau organisasi sosial lainnya (non-profitoriented), ICT dapat digunakan untuk meningkatkan kinerja dan memperbaiki model pelayanan kepada masyarakat yang lebih baik. Sehingga tercipta mekanisme pelayanan pemerintah yang lebih baik, lebih cepat dan lebih murah. Oleh sebab itu, return-nya tidak dapat diukur secara financial semata.

Merujuk kepada Indrajit (2004), minimal ada lima alasan atau tujuan sebuah organisasi melakukan investasi terhadap perangkat teknologi tersebut, yaitu (1) untuk kelangsungan hidup (survive) perusahaan atau bisnis itu sendiri, dengan lain kata, keberadaan ICT di dalam bisnis terkait sifatnya adalah mutlak; (2) ingin memperbaiki efisiensi; (3) untuk memperbaiki efektivitas usaha, dalam arti kata melakukan apa yang diistilahkan sebagai do the righ thing; (4) untuk mendapatkan suatu loncatan keunggulan kompetitif (competitive advantage leap) agar dapat meninggalkan para pesaing bisnisnya dengan mengembangkan teknologi, dimana perusahaan lain belum memiliki; (5) peranan ICT sebagai salah satu perangkat infrastruktur yang tidak dapat dihindari keberadaannya bagi sebuah perusahaan di era global ini.

Namun, berdasarkan beberapa hasil kajian, implementasi ICT pada sebuah organisasi masih sering terjadi kegagalan (failure) yang sangat tinggi (Raja Malik 2003a). Lyytinen dan Hirschheim (1987) dalam Steve Clarke (2001), menyatakan ada empat klasifikasi kegagalan, yaitu (1) kegagalan koresponden; (2) kegagalan proses; (3) kegagalan interaksi; dan (4) kegagalan harapan. Ralph Waldo Emerson (t.th), juga menyatakan bahwa kegagalan bukanlah hanya masalah intalasi sistem teknis, tetapi juga masalah institusional. Isu-isu seperti perilaku, budaya, struktur dan politik sebagai aspek sosial dalam organisisasi perlu dipertimbangkan (Gwo \& Rong 2003; Hackney \& Little 1999). Dengan demikian, faktor manusia merupakan penyebab utama kegagalan implementasi ICT itu sendiri (Raja Malik 2003a).

Akan tetapi hingga hari ini, banyak organisasi sangat tergantung kepada ICT yang merupakan bagian penting (vital) dalam proses bisnis mereka, baik organisasi bisnis maupun instansi pemerintah. Di sini muncul dilematis bagi organisasi yang akan mengimplementasikan ICT. Satu sisi, mereka suka atau tidak, mau atau tidak, harus memanfaatkan kecanggihan ICT untuk mendukung operasional organisasi mereka. Tetapi disisi lain, implementasi ICT dengan investasi yang sangat besar masih sering terjadi kegagalan. Walaupun kegagalan itu sendiri dapat dilihat dari berbagai perspektif. Dengan demikian, nampaknya perlu ada manajemen secara strategik terhadap sumber daya ICT dan infrastrukturnya, sebagaimana manajemen sumber daya organisasi lainnya. Walau bagaimanapun ICT dari sudut pandang manajemen adalah aset yang memberikan sumbangan besar terhadap pengembangan dan reputasi organisasi. 
Berdasarkan uraian di atas, tulisan ini dimaksudkan untuk mendiskusikan dan sharing tentang manajemen strategik ICT khususnya di sektor pemerintahan. Di mana sistem pemerintahan mempunyai sistem manajemen yang unik dibandingkan organisasi bisnis, yang sebenarnya banyak masalah yang harus diselesaikan terlebih dahulu sebelum implementasi ICT di sektor publik/pemerintahan.

\section{Peran Teknologi Informasi Sebagai Media Dasar E-Government}

Proses sistem pemerintahan yang melibatkan ICT sebagai alat untuk memberikan kemudahan proses komunikasi dan transaksi kepada warga negaranya, kini kenali sebagai $e$ government. Sistem ini banyak memberikan keuntungan bagi semua fihak, baik pihak pemerintah sendiri, organisasi bisnis dan masyarakat secara luas. Sehingga semua fihak dapat mencari dan mengetahui informasi serta melakukan transaksi dengan instansi pemerintah kapan dan dimana saja tanpa terbatas oleh ruang dan waktu.

Dilihat dari terminologinya diartikan sebagai konsep manajemen sektor publik yang melibatkan ICT dalam rangka mengoptimalkan proses pelayanan publik secara efisien, terbuka dan efektif. Sehingga tercipta mekanisme pelayanan pemerintah yang lebih baik, lebih cepat dan lebih murah. Pelbagai konsep e-government telah banyak disampaikan oleh beberapa pihak, di antaranya adalah World Bank (2002) memberikan definisi e-government refers to the use of information and communications technologies to improve the efficiency, effectiveness, transparency and accountability of government. Sementara, Berryman (2004) mendefinisikan e-government dihubungkan dengan proses pelayanan yang bersifat on-line, $e$ service, e-administrasi dan $e$ yang lain. Kedua pengertian di atas dimaksud untuk memberikan kemudahan komunikasi dan transaksi antara pemerintah dengan warga negara-nya $\left(\mathrm{G}_{2} \mathrm{C}\right)$, pemerintah dengan organisasi bisnis $\left(\mathrm{G}_{2} \mathrm{~B}\right)$ dan antar lembaga pemerintah $\left(\mathrm{G}_{2} \mathrm{G}\right)$ serta pemerintah dengan stafnya $\mathrm{G}_{2} \mathrm{E}$ (Siau \& Long 2005).

Indrajit (2005) berpendapat bahwa sebuah negara memutuskan untuk mengimplementasikan e-government karena percaya bahwa dengan melibatkan ICT dalam kerangka manajemen pemerintah, akan memberikan sejumlah manfaat, misalnya (1) meningkatkan kualitas pelayanan pemerintah kepada masyarakat dan komunitas lainnya; (2) memperbaiki proses keterbukaan dan akuntabilitas di lingkungan penyelenggaraan pemerintahan; (3) mereduksi kadar biaya transaksi, komunikasi dan interaksi yang terjadi dalam proses pemerintahan; dan (4) menciptakan masyarakat berbasis komunitas informasi yang lebih berkualitas. Sementara, dalam laporan inisiatif e-government pemerintah Federal Amerika Syarikat (Executive Office of the President Office of Management And Budget Washington DC 2002), menyebutkan bahwa signifikansi e-government pada pemerintah, meliputi (1) penyederhanaan penyampaian pelayanan kepada warga negara; (2) membatasi lapisan-lapisan manajemen pemerintahan; (3) memungkinkan warga negara, bisnis, agensiagensi lain dan para staf pemerintahan lebih mudah menemukan informasi dan pelayanan dari pemerintah; (4) menyederhanakan proses bisnis pada agensi pemerintah dan menekan biaya melalui integrasi dan mambatasi sistem yang berlebihan; dan (5) mempersingkat operasional pemerintahan untuk menjamin keperluan warga negara dengan cepat.

Namun, isu yang sangat kuat terhadap implementasi e-government adalah good governance, mekanisme lebih transparan, memperbaiki produktivitas dan efisiensi birokrasi (World Bank 2002; Gupta \& Kumar 2006). Semua manfaat dan signifikansi e-government yang digambarkan di atas, akan terwujud ketika target e-government itu sendiri dapat diwujudkan (Slamet 2007). Alfred (2002) menyatakan bahwa target utama e-government 
adalah terciptanya one-stop-services. ICT merupakan alat untuk mendukung terciptanya ide tersebut. One-stop-services merupakan payung organisasi yang menjalankan di atas fungsifungsi departemen/instansi,pemerintah dengan maksud untuk memaksimalkan kenyamanan dan kepuasan pengguna melalui integrasi pelayanan.

\section{Manajemen Strategik e-Government}

Konsep manajemen strategik tidak hanya menjadi pendekatan dalam manajemen organisasi bisnis (profit-oriented), tetapi juga menjadi pendekatan manajemen organisasi sosial (non-profit), baik yang berukuran besar maupun kecil. Perubahan yang terus-menerus terjadi pada lingkungan organisasi, ini menyebabkan masalah yang rumit dan menantang bagi pimpinan/manajer dalam memanaj organisasi mereka. Pendekatan manajemen strategik tidak hanya melihat masalah-masalah manajemen internal organisasi, tetapi juga memperhatikan apa yang sedang dan akan terjadi pada lingkungan eksternal organisasi.

Beberapa alasan organisasi menggunakan konsep manajemen strategik, di antaranya adalah perubahan lingkungan global, perubahan teknologi, untuk memenangkan dan atau mempertahankan persaingan, dan untuk meningkatkan kualitas (Pitts \& Lei 2006; Dess et al 2006). Konsep manajemen strategik bukanlah sesuatu yang bersifat vacum dan aktivitas sekali dilakukan (McCredie 2000), tetapi manajemen strategik merupakan proses yang berkesinambungan, terintegrasi antara pelbagai faktor utama organisasi dan bersifat fleksibel (Dess et al 2006; Dooris 2003; Robson 1997).

Merujuk kepada Stephen J. Porth (2003), menyatakan bahwa "Strategic management is a process of formulating, implementing and evaluating cross-functional decision that enable the organization to define and achieve its mision, and ultimately to create value", Sementara Khairuddin Mohd. Hashim (2005), menyatakan bahwa "Strategic management is the entrepreneurial process by which a firm accomplishes its objectives through the formulation and implementation of effective strategies based on its distinctive capabilities and external environment". Untuk memudahkan dalam memanfaatkan manajemen strategik dapat dilakukan melalui pendekatan hirarki, yaitu tingkat strategis (corporation strategic), taktik (business strategic) dan tingkat operasional (functional strategic) (Tripomo \& Udan 2005).

Konsep ini masih bersifat umum, namun dapat diimplementasikan kepada berbagai bidang, salah satunya adalah di bidang ICT di sektor publik. ICT dalam sektor pemerintahan perlu dipandang sebagai aset dan sumber daya organisasi yang perlu dimanaj sebagaimana sumber daya organisasi lainnya. ICT di sektor pemerintahan merupakan alat untuk mewujudkan konsep dan target e-government sebagaimana digambar di atas. Oleh sebab itu, konsep dan target e-government dapat dijadikan arahan atau titik akhir dalam me-manaj sumber daya ICT.

Tujuan dari manajemen strategik ICT di sektor publik adalah untuk memastikan sistem manajemen di lingkungan pemerintahan yang berdasarkan komputer dapat dikembangkan, di-manaj dan tentunya perlu penyediaan dukungan untuk operasionalnya. Sehingga pada gilirannya, apa yang menjadi konsep dan target daripada makna e-government itu dapat direalisasikan secara efisien, lebih akurat dan optimal baik segi tenaga kerja maupun biaya. Gambar berikut merupakan hubungan antara konsep dan target e-government, manajemen strategik ICT dan keadaan riel instansi pemerintah saat ini. 


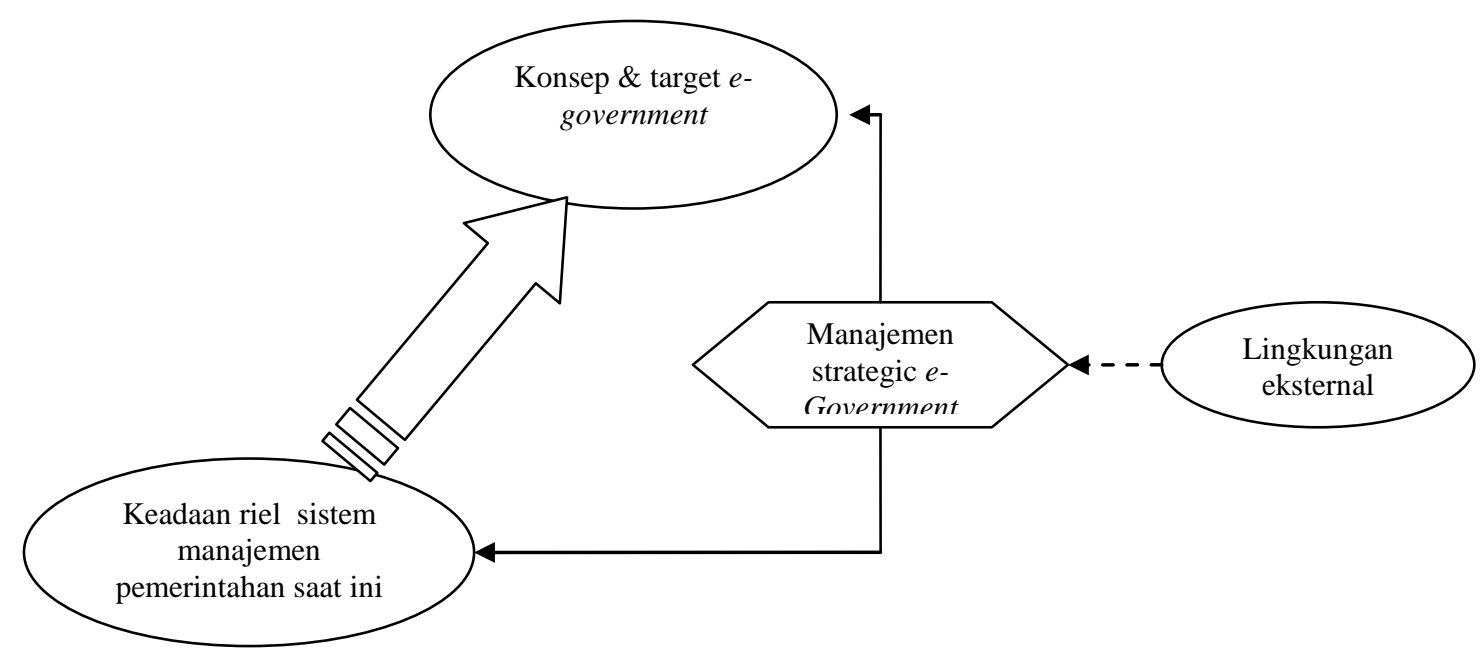

Untuk mencapai tujuan di atas, perlu ramuan pada tingkatan yang berbeda-beda. Merujuk Raja Malik (2003b), manajemen strategik ICT terdapat tiga tingkatan, yaitu tingkatan strategis, tingkatan taktik dan tingkatan operasional. Untuk menghindari atau mengantisipasi kegagalan implementasi ICT, Ralp Waldo Emerson (t.th) menyarankan perlunya analisis resiko pada ketiga tingkatan tersebut. Gambar berikut menunjukkan struktur manajemen strategik ICT.
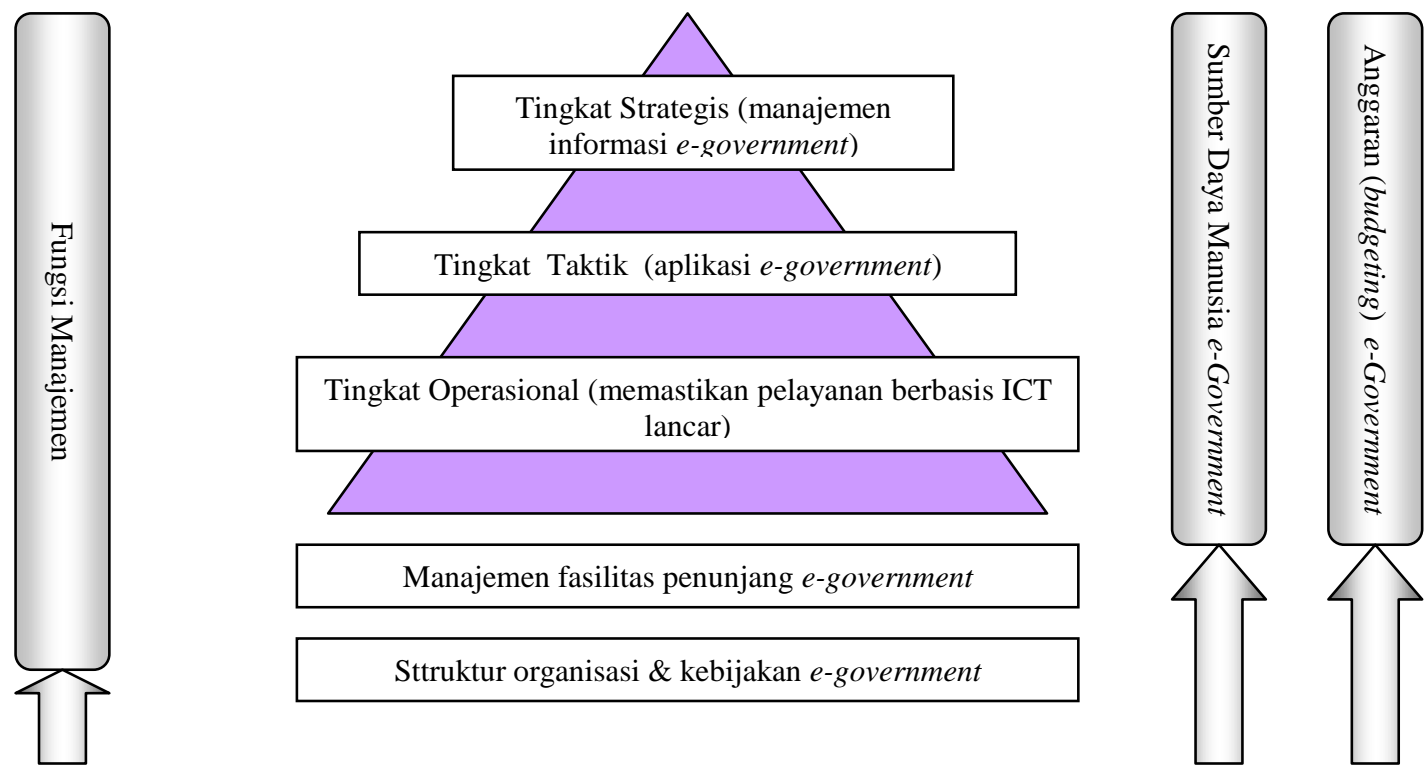

Manajemen Sumber Daya Organisasi e-Government

Sumber : Diolah dari Raja Malik (2003b)

\section{Tingkatan Strategis}


Hirarki pertama dan utama dalam manajemen strategik mana pun adalah tingkatan strategis. Dalam konteks manajemen strategik ICT adalah penentuan arah manajemen $e$ government itu sendiri. Oleh sebab itu, pada tingkatan ini merupakan rumusan besar yang memerlukan energi. Melalui proses perencanaan strategi ICT merupakan langkah tepat dalam merumuskan e-government. Perencanaan strategik ICT merupakan proses merumuskan bagaimana ICT dapat mendukung misi, tujuan dan sasaran organisasi dengan menyelaraskan ICT dengan arahan bisnis (Fitzmaurice 2000). Secara umum, langkah-langkah perencanaan strategik dimulai dengan menentukan visi, misi dan tujuan ICT (e-government), proses penyelarasan antara strategi bisnis organisasi dengan strategi ICT. Langkah ini merupakan langkah strategis menuju suksesnya proyek ICT (Raja Malik 2003b). Langkah kedua adalah analisis lingkungan, baik internal maupun eksternal. Ketiga adalah merumuskan strategik yang relevan untuk implementasinya berdasarkan hasil analisis, SWOT Analysis misalnya, dan terakhir adalah membuat dokumen perencanaan strategik ICT atau blue print $e$ government.

Dokumen ini biasanya berisi informasi yang bernilai sebagai pedoman implementasi ICT, seperti (1) visi, misi, strategi dan daya pendorong strategi bisnis organisasi; (2) visi, misi, strategi dan daya pendorong ICT (e-government); (3) struktur, arsitektur, infrastruktur dan tata kelola (governance) ICT. Governance ICT menyediakan struktur yang menghubungkan proses ICT, sumber daya ICT dan informasi bagi strategi dan tujuan organisasi; (4) peranan, pertanggungjawaban dan proses keputusan yang melibatkan klien, stakeholder, pelaksana dan mitra kerja; (5) model proses dan komponen sistem; (6) manfaat menggunakan ICT; (7) implikasi keuangan; (8) strategi implementasi dan lain sebagainya.

Menurut hemat penulis dalam proses perencanaan strategik ICT, ada tiga hal yang sepatutnya menjadi perhatian bagi perencana ICT di sektor pemerintah, yaitu (1) business process enginering sistem manajemen pemerintahan; (2) restrukturisasi staf; dan (3) domain manusia. Pertama, bukan menjadi rahsia lagi, bahwa manajemen pemerintah adalah sistem yang panjang birokrasinya. Dengan keterlibatan ICT perlu ada rekayasa ulang proses bisnis pemerintahan ini. Indrajit (2005) menyatakan bahwa, e-government tidaklah dapat dibangun dan diterapkan hanya dengan sekedar menyusun peraturan atau kebijakan semata, tetapi memerlukan proses kerja keras yang diawali dengan perubahan paradigma yang bermuara kepada perekayasaan ulang proses yang terjadi di pemerintahan. Kedua, restrukturisasi. Intansi pemerintah merupakan organisasi yang gemuk. Dengan kehadiran ICT tentunya harus ada penataan kembali yang terkait dengan struktur. Hal ini tidak dapat dilakukan kecuali melalui kerjasama dengan Manteri Aparatur Negara (Menpan).

Dalam hal ini, Commonwealth of Kenctucky memberikan rekomendasi terkait dengan implementasi ICT di sektor publik, yaitu (1) pentingnya kepemimpinan yang kuat, yang didukung dengan (a) struktur tata kelola ICT; (b) standard kemampuan operasi organisasi; (c) arsitektur organisasi; dan (d) investasi ICT; (2) perlu panduan arah tujuan, yang meliputi (a) daftar prioritas projek ICT; dan (b) kerangka waktu dan prioritas integrasi data; (3) perlu ada kesinambungan proses (continuity), dengan memperhatikan (a) persyaratan daur hidup (life cycle) ICT; (b) daur hidup manajemen data; (c) perencanaan ICT; (d) pendanaan / anggaran departemen ICT; dan (e) sistem pengadaan ICT; dan (4) untuk mencapai ketiga hal tersebut, diperlukan (a) pekerja profesional di bidang ICT dan berpengetahuan; dan (b) kerjasama dan kemitraan dengan semua stakeholder.

Implementasi ICT pada sebuah organisasi akan berkonsekuensi kepada perubahan, baik perubahan sumber daya manusia, proses, prosedur, sistem maupun arus informasi (Raja 
Malik 2003a). Maka untuk menjembatani konsekuensi perubahan dan mengantisipasi kegagalan implementasi ICT, maka masalah ketiga adalah perlu memperhatikan aspek manusia (human-centred) sebagai domain sosial. Walau bagaimanapun, aspek sosial ini memberikan sumbangan besar dalam kesuksesan implementasi ICT. Hasil kajian McDonagh Joe \& Coglan David (2000) menyatakan bahwa, 90\% keberhasilan implementasi ICT bersumber dari aspek non-teknis, sementara aspek teknis hanya menyumbangkan $10 \%$. Emerson (t.th) juga menyatakan bahwa keberhasilan proyek ICT tidak hanya intalasi sistem secara teknis, tetapi juga masalah institusional baik dalam konteks struktur formal maupun informal. Isu-isu seperti perilaku, budaya, struktur dan politik dalam organisasi perlu dipertimbangkan jika proyek ICT ingin sukses. Oleh sebab itu, pihak yang perlu dilibatkan adalah CIO di lingkungan instansi pemerintah dan semua stakeholder pemerintah yang bersangkutan.

\section{Tingkatan Taktik}

Manajemen strategik ICT pada tingkatan ini merupakan masalah sedikit teknis, dibanding dengan tingkatan manajemen strategik yang pertama. Namun demikian, tingkatan taktik tidak kalah pentingnya dalam mensukseskan konsep sebagaimana yang digambarkan pada tingkatan strategis. Pada tingkatan taktik dalam manajemen strategik ICT adalah terkait dengan pembangunan aplikasi-aplikasi e-government itu sendiri. Aktivitas pada tingkatan ini adalah proses mempelajari persyaratan, penelitian, rancangan desain/aplikasi, mengembangkan aplikasi, mengkaji/memperbaiki, mengganti aplikasi, mengintegrasikan aplikasi dan mengawasi sistem yang terkait dengan sistem e-government.

Pihak-pihak yang perlu terlibat dalam tingkatan taktik adalah analisis sistem, programmer, ahli jaringan, ahli database, ahli web, coding, dan manajer proyek. Untuk suksesnya pada tingkat taktik ini, diperlukan dukungan bisnis dan data base. Dukungan bisnis merupakan interaksi pengembang dengan bisnis organisasi, yang meliputi pengguna (users), stakeholders dan pihak-pihak lain yang mengembangkan dan memproses aplikasi-aplikasi $e$ government Sementara dukungan data base adalah tindakan untuk memastikan bahwa data telah diinputkan, diadministrasikan, dikelola, dianalisis ketika informasi digunakan oleh aplikasi-aplikasi proses bisnis yang terintegrasi.

\section{Tingkatan Operasional}

Manajemen strategik ICT pada tingkatan operasional adalah menyangkut manajemen pusat data. Tugas utamanya adalah memastikan bahwa sistem transaksi telah dioperasionalkan dan dipelihara, sehingga transaksi berdasarkan ICT dapat berjalan lancar setiap saat diperlukan yaitu 24 jam sehari. Oleh sebab itu, customer services merupakan bagian penting dalam manajemen strategik ICT pada tingkat operasional, dengan tugas utamanya adalah memanaj administrasi informasi, terkait dengan informasi pemerintahan yang diperlukan setiap saat oleh masyarakat. Hal ini dapat dilakukan melalui, beberapa cara seperti (1) help desk (one-stop centre dan customer assistance). Masyarakat perlu bantuan secara teknikal ketika menggunakan teknologi ICT; (2) call centre. Masyarakat juga perlu informasi yang disuguhkan oleh pemerintah dan memecahkan masalah terkait informasi yang diterima; (3) audit security. Berfungsi sebagai pengawasan kegunaan dan pelecehan informasi serta untuk mengatur akses informasi; dan (4) recovery. Memastikan bisnis (sistem pelayanan) instansi pemerintah tetap berjalan, walaupun ada gangguan sistem. 
Secara teknis, ahli-ahli yang terlibat adalah para ahli/teknisi hardware, ahli jaringan, ahli manajemen data base dan ahli lain yang relevan. Tugas utamanya adalah memastikan bahwa secara operasional sistem selalu berjalan dengan baik, mengawasi secara berkala terkait space disk, menentukan lokasi data, pengamanan data dan lain sebagainya. Selain itu perlu dukungan staf yang mempunyai pengetahuan, wawasan dan ketrampilan dalam berkomunikasi khususnya pada bagian call centre.

Namun demikian, perlu memastikan bahwa semua data telah diinputkan dan keluaran (output) telah didistribusikan tepat pada waktunya kepada pihak yang memerlukan (customer). Selain me-manaj pusat data, pada tingkat operasional juga perlu me-manaj jaringan telekomunikasi. Pada tahap ini, perlu memastikan bahwa sistem telekomunikasi telah di-install termasuk sistem jaringannya. Selain itu, perlu memperhatikan daur hidup (life cycle) manajemen data maupun teknologinya. Daur hidup data perlu diperhatikan secara berkala bahwa data telah didapatkan, diproses, didistribusikan dan dibuang. Sementara daur hidup yang terkait dengan teknologi yang merupakan salah satu aset yang mempunyai umur ekonomis. Oleh sebab itu, perlu memperhatikan masa-masa replacement.

\section{Manajemen Fasilitas Penunjang Implementasi ICT}

Selain ketiga hal di atas, walaupun tidak terkait dengan tingkatan dalam manajemen strategik ICT secara langsung, manajemen fasilitas sumbangan yang besar dalam kesuksesan implementasi ICT di sektor pemerintah (e-government). Yang bertanggungjawab terhadap manajemen fasilitas adalah manajer administrasi bekerjasama dengan manajer-manajer yang ada di lingkungan departemen ICT. Tugas utamanya adalah mendapatkan fasilitas, pengadaan, instal peralatan, pemeliharaan dan penggantian.

\section{Manajemen Sumber Daya Manusia}

Staf ICT yang profesional dan mempunyai pengetahuan merupakan persyaratan dan elemen paling penting dalam departemen ICT. Mereka-mereka ini perlu di-manaj secara khusus dan baik dengan menempatkan mereka pada tempat yang sesuai sesuai dengan tingkat keahlian dan ketrampilan mereka. Siapakah staf ICT?. Pada tingkat strategis adalah CIO (chief information officer) dan manajer-manajer. Tingkat taktik, terdapat kumpulan staf teknis, seperti analisis sistem, programmer, ahli sistem jaringan, ahli sistem data base, coding design sistem, teknisi hardware, dan lain sebagainya. Sementara para tingkat operasional terdapat staf administrator dan berbagai operator.

Dalam kontek pemerintah di Indonesia, staf ICT sebagian besar belum memenuhi sebagaimana yang disyaratkan oleh departemen ICT. Manajemen ICT di Pemerintahan Daerah misalnya, diurus oleh seseorang dengan jabatan Kepala Pengelola Data Elektronik (KPDE). Merujuk kepada peraturan pemerintah daerah kota X, bahwa KPDE sebagai lembaga teknis. Memperthatikan ruang lingkup manajemen strategik di bidang ICT begitu luas dan strategis, maka sepatutnya perlu ada restrukturisasi dari KPDE manjadi CIO e-government yang setingkat dengan asisten di Pemerintah Paerah (Slamet 2007). Tugas utama CIO adalah membuat perencanaan, koordinator antara kantor dinas, pemantauan dan manajemen budget serta bertanggungjawab mulai dari tingkat strategis hingga manajemen sumber daya yang terkait dengan implementasi e-government. 
Gambar berikut contoh struktur departemen ICT :

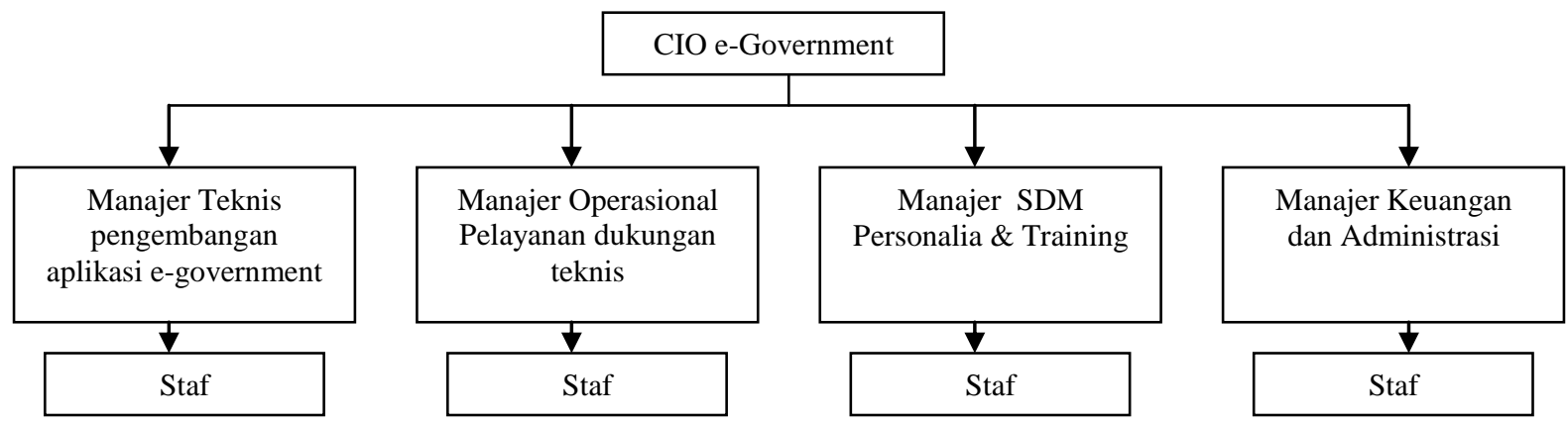

Sumber : diadaptasi dari Raja Malik (2003b)

\section{Manajemen Keuangan ICT}

Salah satu aspek penting yang perlu dipahami dalam departemen ICT adalah manajemen keuangan (Emerson t.th). Hal ini merupakan salah satu sumber daya organisasi yang penting demi kehidupan departemen ICT. Merujuk kepada Ralph Waldo Emerson (t.th) menyatakan ada tiga fungsi pokok manajemen keuangan dalam departemen ICT, yaitu budgeting, costing dan charging. Budgeting merupakan proses meramalkan dan mengawasi pengeluaran uang. Adapun ruang lingkup anggaran (budget) ICT, yakni memperoleh anggaran dan pengawasan terhadap pengeluaran anggaran (Raja Malik 2003b). Untuk mendapatkan anggaran yang logis dan relevan demi operasional e-government, maka perlu dukungan dokumen perencanaan ICT secara baik, sebagaimana yang digambarkan pada tingkatan strategis. Aspek penting yang perlu di-cover selama proses penganggaran meliputi aspek peralatan (equipment), susunan personalia (staffing), manajemen fasilitas, training staf dan lain sebagainya.

Costing merupakan pengeluaran riel yang terjadi pada departemen ICT. Tabel berikut merupakan rancangan alokasi pengeluaran riel (costing) pada departemen ICT pada umumnya

\begin{tabular}{|l|l|l|}
\hline No & \multicolumn{1}{|c|}{ Tipe biaya } & \multicolumn{1}{c|}{ Elemen-elemen biaya } \\
\hline 1 & Hardware & $\begin{array}{l}\text { CPUs. Storage, peripherals, WAN, LAN, workstation, laptops, } \\
\text { PDAs, consumables dan lain sebagainya. }\end{array}$ \\
\hline 2 & Software & $\begin{array}{l}\text { Operating systems, monitoring tools, database management } \\
\text { systems, aplication servers, web servers, mail services, packaged } \\
\text { applications, homemade applications, personal productivity } \\
\text { tools, groupware dan lain sebagainya. }\end{array}$ \\
\hline 3 & Human resources & Payroll costs, benefits, re-location cost, expenses, training dan \\
\hline
\end{tabular}




\begin{tabular}{|l|l|l|}
\hline & & lain sebagainya. \\
\hline 4 & Accommodation & $\begin{array}{l}\text { Offices, furniture, computer rooms, storage areas dan lain } \\
\text { sebagai }\end{array}$ \\
\hline 5 & External services & $\begin{array}{l}\text { Security services, disaster recovery services, outsourcing } \\
\text { services, consultancy, telecom charges dan lain sebagainya. }\end{array}$ \\
\hline
\end{tabular}

Sumber : Walph Waldo Emerson (t.th).

Dalam hal ini, Commonwealth of Kentucky (2003-2007) dalam sebuah dokumennya menyarankan terkait dengan investasi di bidang ICT untuk memastikan bahwa sumber daya sumber daya ICT diberdayakan dan diintegrasikan dengan baik dan di-manaj secara aktif. Karena lingkungan ICT berubah dengan cepat dan kompleks. Oleh sebab CIO e-government instansi pemerintah perlu memanaj semua misi projek agensi-agensi (kantor dinas/instnasi pemerintah) untuk memaksimumkan investasi ICT. Manajemen secara aktif pada tingkat instansi pemerintah secara keseluruhan akan menghasilkan perbaikan operasional secara signifikan, meningkatkan ketersediaan dan meningkatkan interaksi di antara institusi-institusi pemerintah lainnya. Sedangkan charging adalah pembebanan kepada customer sebagai pengguna jasa ICT. Charging merupakan metode untuk menyeimbangkan antara mutu dan kuantitas yang diberikan oleh departemen ICT. Namun demikian tidak semua instansi pemerintah menerapkan metode charging ini.

\section{KESIMPULAN}

Berdasarkan paparan di atas, maka dapat disimpulkan bahwa ICT merupakan salah satu alat yang mempunyai peran penting dalam kehidupan manusia saat ini, khusus pada instansi pemerintah yang mampu memberikan model pelayanan kepada masyarakat lebih murah, lebih baik, lebih nyaman dan lebih cepat. Keterlibatan ICT pada sistem manajemen pemerintahan kini dikenal dengan istilah e-government. Di mana e-government mempunyai manfaat yang sangat besar, baik pihak pemerintah sendiri, organisasi bisnis maupun warga masyarakat. Untuk mewujudkan manfaat daripada e-governmenti, maka target e-government harus terpenuhi. Namun, untuk memenuhi target tersebut masih banyak masalah yang perlu diselesaikan terlebih dahulu, di antaranya adalah perubahan paradigma, mengantisipasi kegagalan, diperlukan investasi yang cukup besar, terjadinya perubahan dalam internal instansi pemerintah bersangkutan (integrasi).

Salah pendekatan untuk mencapai target e-government yang sebagaimana yang diharapkan adalah menggunakan manajemen strategik yang dikaitkan dengan ICT. Manajemen strategik ICT mempunyai tiga tingkatan hirarki, yaitu tingkatan strategis, taktik dan operasional yang didukung oleh manajemen sumber daya organisasi sebagai penunjang terlaksananya manajemen strategik ICT. Ketiga tingkatan hirarki dalam manajemen strategik ICT mempunyai arah, tugas dan tanggungjawab yang berbeda-beda, tetapi ketiga tingkatan tersebut merupakan satu kesatuan yang tidak dapat dipisah-pisahkan. 


\section{DAFTAR RUJUKAN}

Alfred, Tat-Kei Ho. 2002. Reinventing local government and the e-government initiative. The Premier Journal of Public Administration Review (PAR). July-August. 62(4): 434444.

Berryman, Jennifer. 2004. E-government: issues and implicationsfor public libraries. http://www.alia.org.au .

Clarke, Steve. 2001. Information systems strategic management: an integrated approach. London: Routledge.

Commonwealth of Kenctucky. 2003-2007. The direction of enterprise information technology.

Dess, G., Gregory, Lumpkin, G.T. \& Eisner, B., Alan. 2006. Strategic Management. Kuala Lumpur: McGraw-Hill Irwin.

Dooris, J., Michael. 2003. Two decades of strategic planning. Journal Planning for Higher Education. 31(2): 26-42.

Emerson, Ralph Waldo. t.th. Financial Resources. Sample 5.

Fitzmaurice, Michael. 2000. Teknology strategic planning. http://web.ukonline.co.uk.

Gwo, G.L. \& Rong, J.B. 2003. Organizational mechanisms for succesful IS/IT strategic planning in the digital era. Journal Management Decision. 41(/): 32-42.

Gupta, M.P. \& Kumar, Prabhat. 2006. e-governance impacts Gujarat :: Corruption reduced, tax revenues increase at interstate border checkposts. http://www.egovonline.net

Hackney, R. \& Little, S. 1999. Opportunistic strategy formulation for IS/IT planning. European Journal of Information Systems. 8():119-126.

Indrajit, E.R. 2004. Kajian strategis: cost benefit teknologi Informasi (panduan investasi pengembangan TI di perusahaan). Yogyakarta: Andi Offset.

Indrajit, E.R., Rudianto, D. \& Zainuddin, A. 2005. E-government in action. Yogyakarta: Andi Offset.

Keng, Siau \& Yuan, Long. 2005. Synthesizing e-government stage models - a meta-synthesis based on meta-ethnography approach. Journal Industrial Management \& Data Systems. 105(4): 443-458.

Khairuddin, Mohd., Hashim. 2005. Strategic management. Australia:Thomson.

Kumorotomo, Wahyudi, \& Margono, Agus, Subando. 1996. Sistem informasi manajemen dalam organisasi publik. Yogyakarta: Gadjah Mada Press.

McCredie, W.John. 2000. Planning for IT in higher education: it's not an oxymoron. Journal Educause Quarterly. (4): 14-21. 
McDonagh, Joe \& Coghlan, David. 2000. Sustaining the dilemma with IT-related change: the fortuitous role of academia. Journal of European Industrial Training. 24(5): 297-304.

Office of Management and Budget. 2002. E-government strategy (simplified delivery of services to citizens). February 27, 2002.

Pitts, A., Robert \& Lei, David. 2006. Strategic management (building and sustaining competitive advantage). Ed. ke 4. Australia: Thomson.

Porth, J., Stephen. 2003. Strategic management (a cross-functional approach). New Jersey: Prentice Hall.

Raja, Malik Mohamed. 2003a. Practical approach to ICT strategic planning. Kuala Lumpur: Institut Tadbiran Awam Negara (INTAN).

Raja, Malik Mohamed. 2003b. Challenges in managing Information \& Communications Technology: A CIO Guide. Kuala Lumpur: Institut Tadbiran Awam Negara (INTAN).

Robson, Wendy. 1997. Strategic management \& information systems. Ed. ke 2. England: Prentice Hall.

Tripomo, Tedjo \& Udan. 2005. Manajemen strategi. Bandung: Rekayasa Sains.

Slamet, et.al. 2007. Restrukturisasi dan reorientasi menuju percepatan target e-government di Indonesia. Prosiding Konferensi Nasional Sistem Informasi 2007. hlm. 565-570.

World Bank. 2002. The e-government handbook for developing countries. A project of infodev and the center for democracy and technology. 